\title{
Determinants of health expenditure from global perspective: A panel data analysis
}

\author{
Muhammad Awais*1-2 Alam Khan $^{1} \mid$ Muhammad Salman Ahmad ${ }^{3}$ \\ 1. Department of Economics, Kohat University of Science and Technology (KUST), Kohat, Pakistan. \\ 2. Department of Economics, Quaid-e-Azam University (QAU), Islamabad, Pakistan. \\ 3. School of Political Science \& Public Administration, Neijiang Normal University, Sichuan, China.
}

*Corresponding Author Email: awaiseco217@gmail.com

\begin{abstract}
A prominent enhancement in health expenditure is a severe apprehension for the whole world because of the increasing cost of health. Consideration of various aspects that are playing role in the increase of health expenditure need to be considered. Health is one of the significant parts of the world, therefore, improvement in health status has become the main objective of the nations and a top leading goal of the Sustainable Development Goals (SDGs) and Millennium Development Goals (MDGs). The main goal of the present study is to investigate the worldwide, and income-based categorized countries (developed, developing, and transitional countries) macroeconomic determinants of health expenditure. The aim is to estimate the health expenditures, and its impact on demographic, economic, and environmental determinants. For the empirical analysis, the data was retrieved from the World Bank, covering the time span 2000-2016 for developed, developing, and transitional countries. The results of the study concluded that macroeconomic variables significantly affect health expenditures. Moreover, personal remittances have a dual effect on health expenditure, i.e., a positive impact on transitional economies, while a negative impact on developing economies. In the same way, $\mathrm{CO} 2$ emission has a negative impact on worldwide, developed countries.
\end{abstract} Article History

Received:

March 28, 2021

Last Revised:

June 21, 2021

Accepted:

June 24, 2021

Published:

June 29, 2021

Keywords: health expenditure, economic performance, panel data analysis, random effect model, fixed effect model, personal remittances, socio-economic factors.

\section{How to Cite:}

Awais, M., Khan, A., \& Ahmad, M. S. (2021). Determinants of health expenditure from global perspective: A panel data analysis. Liberal Arts and Social Sciences International Journal (LASSIJ), 5(1), 481-496. https://doi.org/10.47264/idea.lassij/5.1.31

Publisher's Note: IDEA PUBLISHERS (IDEA Journals Group) stands neutral with regard to the jurisdictional claims in the published maps and the institutional affiliations.

Copyright: () 2021 The Author(s), published by IDEA PUBLISHERS (IDEA Journals Group). This is an Open Access article published under the Creative Commons Attribution-NonCommercial 4.0 International License (http://creativecommons.org/licenses/by-nc/4.0/) 


\section{Introduction}

Good health is fundamental component for the human pleasure and prosperity and performs a major role in financial growth. Consequently, healthy people are more productive, efficient, and can live longer but on the other side, health care and health financing are emerging issues throughout the world. According to Aremu (2019), financial capital is an important input to the wellbeing system, but scarce economic resources are the global restraints faced by all wellbeing systems. According to World Health Organization (WHO), the health financial system grows much faster than the worldwide economy and spent 7.3 trillion in the year 2015 which is near to $10 \%$ of the global income. Moreover, the yearly development rate of health expenditure from the time $2000-2015$ was $4 \%$ whereas the financial growth rate was $2.8 \%$ (WHO, 2018).

To encounter the health problems, the United Nations General Assembly (UNGA) in the year 2000 decided to accomplish the Millennium Development Goals (MDGs) for the period 20002015. But there were several prominent issues i.e., limitation of infection programs, and virtualization of the wellbeing of the people (WHO, 2015). So, due to the presence of several restrictions in MDGs, the UNGA adopted a new agenda of sustainable development goals (SDGs) from 2015-2030. This new program covers the financial, public, and atmospheric aspects. In the SDGs, health is one of the most important goals and it places a central position to confirming healthy lives and encourages health for all ages, and open links to many of the other goals (WHO, 2016).

The health care spending holds a large share of the government budget, but the government continuously tries to reduce its expenditure to relax the budget. However, it's difficult for people to shrink their costs specifically in the wellbeing care sector (Samadi \& Rad, 2013). Healthcare expenditure (HCE) and its determinants are the main worries in most of the countries. Health policymakers in developed and developing countries are concerned about rising healthcare expenditure and are interested to identify the main factors affecting these costs (Rezaei, et al., 2016).

\subsection{Hypotheses of the study}

Better wellbeing is integral to the human basic fulfillments. There are numerous impacts that control wellbeing status and it is the capacity of the country to organize esteem wellbeing administrations for its general population. Wellbeing use is one of the featured issues on the planet. Thus, the current examination is going to explore the following hypothesis:

$H_{0}^{1}$ : Macroeconomic factors have no impact on the health expenditure.

$H_{1}^{1}$ : Macroeconomic factors have significant impact on the health expenditure.

\subsection{Objective of the study}

Remembering that prosperity plays out a principal part in teaching the day to day environment of the general population. In general, the aspire of the work is to consider the connection among macroeconomic factors on applying the board information assessment of pay based nations, areas shrewd and overall nations. The aim of this empirical investigation is to empirically examine the connections among macroeconomic determinants with health expenditure and furthermore to explore the macroeconomic factors which affect health expenditure. 


\subsection{Research gap}

In the previous few decades' different research have been done to examine the factors of H.E for Pakistan, Korea, Saudi Arabia, Swiss Cantons, United States and Canada, Organization for Economic Cooperation and Development (OECD), developed countries, Economic cooperation organization (ECO), and for African countries. But to the best of information, there are no such research found that explore the macroeconomic variables of health expenditure in detail. This present study explores the demographic, economic, and environmental factors of health expenditure Worldwide, and for the income-based categorize countries (developing, transitional and developed countries).

Moreover, in the previous different studies, they separately investigated the effect of foreign direct investment (FDI) on H.E, personal remittances (PR) on health expenditure, CO2 emission on health expenditure, and trade openness (TO) on health expenditure respectively. Besides, none of the studies incorporate all these variables into one platform to enlighten the macroeconomic determinants of health expenditure (DHE). In the current study, we incorporate all these factors to discover the macroeconomic DHE for the whole world, and for the developing, transitional, and developing countries.

For examination of the macroeconomic factors of health expenditure, the rest of the paper is categorized into five sections. After an explanation of section 1 (1.1,1.2, and 1.3), section 2 offers a detailed review of different studies, section 3 explained the theoretical framework and conceptual framework. Similarly, section 4 explains the data and variables, methodology, and econometric specification. While in the last two sections, we discussed the result \& discussion and conclusion \& suggestion.

\section{Literature review}

Examination of DHE has gotten one of the significant apprehensions for health policymakers and planners. Several works have been directed worldwide to explore the DHE in a country. This segment of the paper reviews a portion of the writing in this regard. To start with the general views, the research examined various determinants of medical care. Newhouse (1977) investigated the determinants of medical care and concluded that 90 percent of the dissimilarity in well-being expenditure is mainly due to gross domestic product (GDP) per capita, and the study further concluded that health care is luxury. It has been studied, for example, by Freeman (2003), Baltagi \& Moscone, (2010), Abbas \& Hiemenz (2011), and Murthy \& Okunade (2016) found a very strong association among GDP and H.E and they concluded that well-being care is necessities because income elasticity is less than one. Also, GDP is widely found to be a variable that most responsible for the changes in the level of health expenditure (Hitiris \& Posnett, 1992; Toor \& Butt, 2005; Rezaei et al., 2016 and Akca et al., 2017).

In recent decades several studies consider the effect of $\mathrm{CO} 2$ emission on H.E (health expenditure). In the study of Apergis et al. (2017) discussed the CO2 emission effect on health expenditure. They reported the positive effect of $\mathrm{CO} 2$ emission on health expenditure and further investigate that the impact is more grounded for those areas which spend a higher amount on health expenditure. Similarly, Yazdi et al., (2014) examine the positive impact of $\mathrm{CO} 2$ emission on health expenditure. Although Lu et al., (2017) concluded the adverse effect of $\mathrm{CO} 2$ emission and other environmental-related pollution on community well-being but they further found that $\mathrm{CO} 2$ emission has a significant contribution to growth and health promotion. 
Moreover, Boachie et al. (2014) observe that a negative relationship exist between CO2 emission and H.E.

In the same context, urbanized people have more access to health-related goods and services. According to Rezaei et al. (2016), urbanization is one of the pouring forces behind the continuous increase in health care expenditures. Moreover, Samadi \& Rad (2013) concluded in their study that the association exists between urbanization and H.E is positive. While some other studies reported the negative association between urbanization and health expenditure (Abbas \& Hiemenz, 2011; Cumper, 1984; Toor \& Butt, 2005; Siddiqui et al., 1995).

Also, FDI consumes a twin consequence on wellbeing spending. The foreign direct investment might have a significant effect on people's well-being mainly by raising the interest for such goods and services which are related to health, and by improving the stock of such products and services. Likewise, FDI has a significant influence on H.E in low-income countries (Nagel et al., 2015). In contrast to the positive effect, foreign direct investment might have negative effects on populace well-being by giving growth to larger disparity in the host economies. Besides, Herzer \& Nunnenkamp (2012) found a negative effect of FDI on wellbeing expenditure in developed countries.

Correspondingly, the inflow of migrant's revenue has a significant effect on H.E (Gil, 2008 and Dorantes \& Pozo, 2009). Furthermore, remittances perform a crucial role in decreasing poverty in the beneficiary economies and a positive effect on literacy and wellbeing (Acosta $e t$ al., 2007). Additionally, there is a positive and significant effect of remittances on well-being knowledge (Ponce et al., 2011). Moreover, trade has a greater result on those economies which are less developed, high-income taxes, and they encourage spending on health (Herzer, 2017). Additionally, in developing countries trade openness linked with low infant mortality rates and average life expectancy (Owen \& Wu, 2002). Furthermore, trade frankness has an important association with life expectancy (LE), health financing, the negative and major connection between trade openness and infant mortality rate (Novignon \& Atakorah, 2016).

Several studies analyze that life expectancy is one of the major variables to identifying health expenditure (Akca et al., 2017) as well as LE has a positive and important effect on infant death rate (Mostepaniuk \& Parish, 2019; and Bech et al., 2011). Though, the increasing expectancy of life by one year leads to rising foreign inflow of investment by 9\% (Alsan et al.,2006). Likely, some other study found that unemployment hurts health spending i.e. (Abbas \& Hiemenz, 2011) in line with this study (Braendle \& Colombier, 2016) inspect that the unemployment rate is highly positive related to public wellbeing spend.

Although, population age plays important role in increasing health expenditure like the ratio of the population above 65 years' age exerts a positive impact on wellbeing expenses (Murthy \& Okunade, 2016; and Samadi \& Rad, 2013). In the same manner, literacy is one of the driving services behind the continual growth in health expenditure (Rezaei et al., 2016). Moreover, education plays an important role in raising health expenditure. Literacy is an essential variable and significant relationship with healthcare expenditure (Toor \& Butt, 2005).

\section{Theoretical framework}

Two distinguishing methodologies have been used to investigate the association among H.E and Health outcomes, both the methodology was rooted in the work of Grossman on human 
capital theory (Grossman, 1972). To begin with, the concept regards health as both a consumption and investment goods. The aim of the individual while consuming health is to maximize utility subject to its budget constraint, along with qualities that affect individual health. Furthermore, within this model income level and literacy level assume noticeable parts as informative factors. Additionally, the model further differentiates between health care and health, the last being one of the numerous inputs into the production of health goods. The model of investment demand concern with observed examination as well as with theoretical examination of demand for the health commodity. The model regards well-being as a wealth good that is inborn and denigrates over time. According to the theory, investment in well-being is a process in which health care is together with relevant factors to yield new wellbeing, which partially balances the interaction of devaluation of the well-being stock.

The subsequent methodology considers health within a framework of the production function. The fundamental hypothesis of this methodology is that wellbeing is a yield of a wellbeing care system, which is impacted by the contributions to the framework. This method of examination is useful to explore the association among the inputs (H.E) and outputs (well-being outcomes) of the system. Our observed investigation emphasizes the second approach, which is good for macro-level data analysis. The large-scale investigation is more appropriate considering that, critically and experimentally, micro-level outcomes for well-being policy executive at the macro level can be ambiguous (Nixon \& Ulmann, 2006).

\subsection{Conceptual Framework}

Figure-1 explains the conceptual framework, where the dependent variable is health expenditure while trade openness GDP FDI remittance, urbanization demographic factors and $\mathrm{CO}_{2}$ are independent variables. According to Han et al. (2013) and Murthy and Okunade (2016) Health expenditure is positively connected with age of the population. Furthermore, population of the elderly in the total population increases lead to rise the health expenditure. In the same way, life expectancy increases the contribution of the populace of old and positive relationship with well-being spending. According to Rezaei et al. (2016) the literacy rate in the society might help people to improve wellbeing consciousness and increase the utilization of the healthcare service. Toor and Butt mentioned in their studies that crude birth rate increases the rate of keeping a given well-being level. So, there is positive association among crude birth rate and health care expenditure.

Unemployment is positively linked with health expenditure because if a person is unemployed mean that the person has low income which leads to have insufficient consumption of basic goods and this deficiency increases the risk of illness (Forbes \& Mcgregor, 1984). Furthermore, Herzer and Nunnenkamp (2012) stated that foreign direct investment has direct effect inside firms, economy wide while backhanded impacts on wellbeing could follow from FDI-initiated development to the degree that higher normal earnings bring about more interest in wellbeing administrations. Gross domestic product is one of the influential factors which affect health expenditure. According to Samadi and Rad (2003) countries with great financial framework have more information about the advantages of medical services and thus use medical care more than different countries. In the same manner, the income which is come from abroad mean remittances has been used by household for variety of reasons on both sides of instant utilization to long-term speculations for human turn of events, like training and wellbeing (Thoumi, 2016). In addition, trade openness leads to raise income leads to raise in expenditure both in private and public, on goods that improve health, (Herzer, 2017). 
The environmental factors urbanization and $\mathrm{CO} 2$ emission have significant impact on wellbeing spending. According to Atuahene et al. (2020) CO2 emissions have a positive and measurably huge impact on wellbeing consumption. Surmising that more hurtful substances are being delivered in the climate, making the public authority spend on wellbeing administrations. Also, Urbanization followed by the rise of congestion shantytowns with lacking clean condition, congestion, and industrialization cause air contamination. In this way we expected that urbanization decidedly related with wellbeing use (Gbesemete and Gerdtham, 1992 and Toor and butt, 2005).

Figure-1: Conceptual Framework

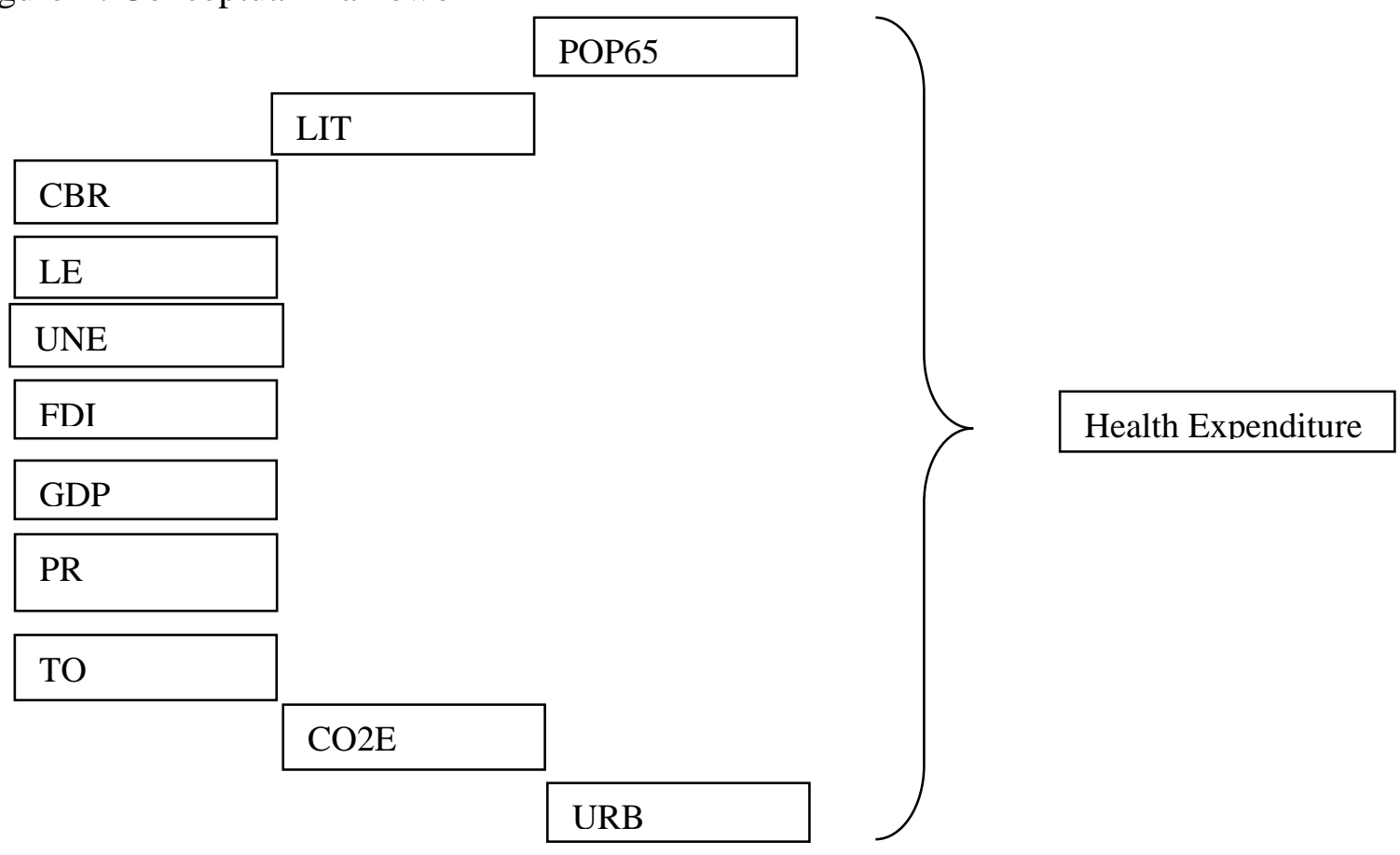

\section{Data and methodology}

\subsection{Data variable}

The information for the study was retrieved from the World Bank (W.B) in the year 2019, covering the time from 2000-2016. Based on data availability, the panel of 132 countries was constructed and further classification of the panel data into developed, developing, and transitional countries based on World Economic Situation Prospects (2019). With an evaluation of the literature, the variables measured to act on H.E were recognized and employed as exogenous study variables, and these variables are gross domestic product, foreign direct investment, personal remittances, trade openness, CO2 emission, urbanization, literacy, unemployment, crude birth rate, life expectancy, and population age 65 and above (POP65).

\subsection{Methods}

To investigate the impact of macroeconomic DHE, Pooled OLS (POLS), Random effect model (REM), and Fixed effect model (FEM) are used, and based on Breusch-Pagan test Lagrange multiplier (LM) we select either POLS or REM while on the bases of Hausman test we select one of the models among FEM and REM. The selection of the model is based on the P-value. 
Figure 2: Determinants of Health Expenditures (DHE)

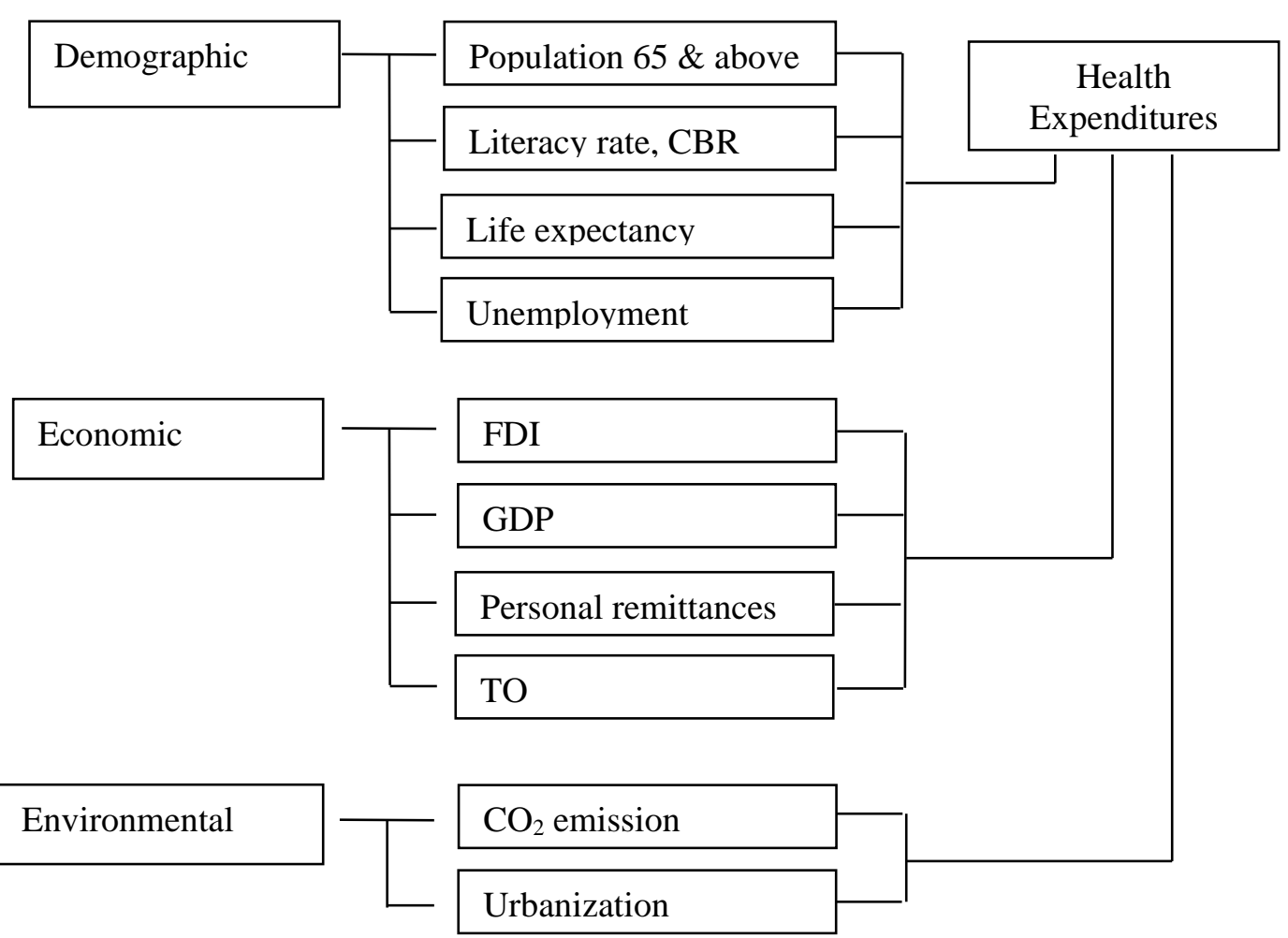

\subsection{Econometric specification}

The model is attempting to look at the essential DHE and to test the association among healthcare expenditure and its determinants across the world, developed, developing, and in transition countries. So, for the empirical investigation, the objective of the study is to apply econometric techniques to search the impact of demographic, economic, and environmental determinants of health expenditure.

$$
\begin{gathered}
h_{i t}=\alpha_{0}+\alpha_{1} F D I_{i t}+\alpha_{2} P R_{i t}+\alpha_{3} T O_{i t}+\alpha_{4} C O 2_{i t}+\alpha_{5} \ln G D P_{i t}+\alpha_{6} \ln L I T_{i t}+ \\
\alpha_{7} \ln L E B_{i t}+\alpha_{8} \ln U N E_{i t}+\alpha_{9} U R B_{i t}+\alpha_{10} P O P 65_{i t}+\alpha_{11} \ln C B R_{i t}+\epsilon_{i t}(1)
\end{gathered}
$$

Here, a subscript $i$ is used for the cross-sectional unit whereas subscript $t$ is used for the timeperiod. Where $h$ is the current health expenditure demonstrating a percentage of GDP, FDI foreign direct investment is the net inflow which is identified as a percentage to GDP, PR (personal remittances percentage to GDP), TO (trade openness is the summation of imports and exports of goods and services measured as a share of GDP), CO2E (carbon-di-oxide emission in metric tons per capita), LnGDP (the logarithm of gross domestic product per capita at purchasing power parity), LnLIT (the logarithm of primary school enrollment percentage of gross is used as a proxy for literacy), LnLEB (life expectancy at birth), LnUNE (Unemployment mentions the part of the labor force that is deprived of work but obtainable for and looking for employment), URB (percentage of people who lived in urban relative to the total population), POP65 (population age 65 and above a share of the total population) and CBR (crude birth rate per 1,000 people).

Before moving toward empirical analysis, we would like to perform an exploratory analysis of our data. Figure 3 provides detailed information on developed, developing, and transitional 
countries' contribution toward total health expenditure. It can be seen from the figure- 3 that developing countries are on top of contributing to total health expenditure. Moreover, the contribution to H.E is greater in developed countries than in transitional countries. The information is taken from the World Bank (2019).

Figure 3: Developed, developing and transitional countries contribute toward health expenditure.

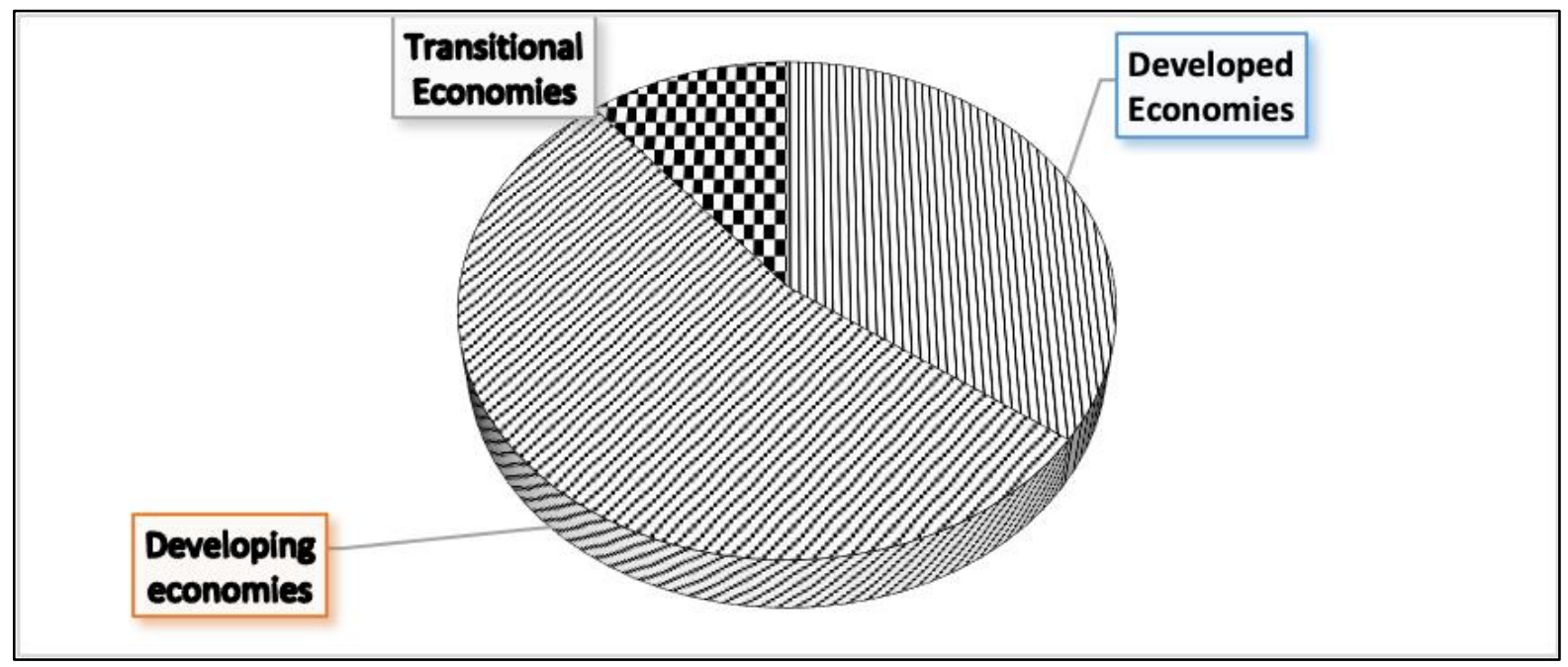

Source: Authors' work.

\section{Result and discussion}

The empirical outcome of the models for the global analysis, developed, transitional, and developing countries are offered in Tables 1, 2, 3, and 4. Column 1 shows the list of variables while the remaining columns show the outcome of the worldwide, developed, transitional, and developing countries correspondingly. The model shows the linkage among endogenous variable health expenditure and with exogenous variables i.e. FDI, PR, TO, gross domestic product, CO2e, URB, LIT, LEB, CBR, UNE, and percentage of populace age above 65 . Table1 demonstrates the descriptive statistics of the research variables. It includes maximum and minimum values, range, mean, and standard deviation.

Table1(a): Descriptive Statistics

Worldwide

Developed countries

\begin{tabular}{|l|l|l|l|l|l|l|l|l|l|l|l|}
\hline Varia. & Obs & Mean & St.Dev & Min & Max & Varia. & Obs & Mean & St.Dev & Min & Max \\
\hline CHE & 2244 & 6.314 & 2.32 & 1.6 & 17.073 & CHE & 595 & 8.327 & 2.056 & 4.188 & 17.073 \\
\hline FDI & 2244 & 5.429 & 17.086 & -58.323 & 451.716 & FDI & 595 & 9.35 & 31.933 & 58.323 & 451.716 \\
\hline PR & 2244 & 4.059 & 6.692 & -9.27 & 53.826 & PR & 595 & 1.11 & 1.313 & .034 & 8.19 \\
\hline TO & 2244 & 83.857 & 46.352 & 294.175 & 416.389 & TO & 595 & 104.576 & 61.448 & 22.154 & 416.389 \\
\hline lnGDP & 2244 & 25.179 & 2.101 & 19.925 & 30.627 & 1GDP & 595 & 26.306 & 1.611 & 22.985 & 30.464 \\
\hline CO2 & 1980 & 4.661 & 6.393 & .021 & 67.311 & CO2 & 525 & 8.707 & 4.208 & 2.683 & 24.825 \\
\hline URB & 2244 & 55.863 & 22.824 & 8.246 & 100 & URB & 595 & 74.074 & 12.147 & 50.754 & 97.919 \\
\hline lnLIT & 2244 & 103.437 & 12.997 & 32.322 & 154.744 & LIT & 595 & 101.552 & 4.374 & 89.448 & 124.85 \\
\hline $\operatorname{lnLEB}$ & 2244 & 4.242 & .141 & 3.75 & 4.426 & lLEB & 595 & 4.362 & .041 & 4.252 & 4.426 \\
\hline $\operatorname{lnCBR}$ & 2244 & 2.939 & .501 & 2.041 & 3.98 & 1CBR & 595 & 2.381 & .151 & 2.054 & 2.815 \\
\hline UNE & 2244 & 7.881 & 6.025 & .14 & 37.25 & UNE & 595 & 8.191 & 4.295 & 1.805 & 27.466 \\
\hline POP65 & 2244 & 8.36 & 5.481 & .715 & 22.235 & POP65 & 595 & 15.855 & 2.548 & 10.229 & 22.235 \\
\hline
\end{tabular}


Table1(b): Descriptive Statistics

\begin{tabular}{|c|c|c|c|c|c|c|c|c|c|c|c|}
\hline \multicolumn{6}{|c|}{ Developing countries } & \multicolumn{6}{|c|}{ Transitional countries } \\
\hline $\begin{array}{l}\frac{0}{0} \\
\frac{\pi}{\tilde{\sigma}} \\
> \\
>\end{array}$ & ô & $\stackrel{\bar{\Xi}}{\Sigma}$ & $\begin{array}{l}\overrightarrow{\mathrm{D}} \\
\stackrel{\vec{z}}{\mathrm{in}}\end{array}$ & $\stackrel{\Xi}{\Sigma}$ & $\stackrel{\ltimes}{\Sigma}$ & $\begin{array}{l}\frac{0}{D} \\
\frac{.0}{\tilde{J}} \\
>\end{array}$ & ô & $\sum_{\Sigma}^{\varpi}$ & 离 & $\stackrel{\Xi}{\Sigma}$ & $\stackrel{\ltimes}{\Sigma}$ \\
\hline CHE & 1411 & 5.437 & 1.913 & 1.6 & 12.403 & CHE & 238 & 6.476 & 1.945 & 2.692 & 13.677 \\
\hline FDI & 1411 & 3.684 & 4.289 & -37.1 & 43.912 & FDI & 238 & 5.97 & 6.383 & -.172 & 55.076 \\
\hline PR & 1411 & 4.342 & 6.518 & -7.378 & 53.826 & PR & 238 & 9.753 & 10.576 & -9.27 & 49.29 \\
\hline TO & 1411 & 74.191 & 37.665 & -294.1 & 220.407 & TO & 238 & 89.366 & 27.675 & 24.17 & 175.351 \\
\hline lGDP & 1411 & 24.753 & 2.19 & 19.925 & 30.627 & IGDP & 238 & 24.889 & 1.545 & 22.725 & 28.939 \\
\hline $\mathrm{CO} 2$ & 1245 & 2.966 & 6.731 & .021 & 67.311 & $\mathrm{CO} 2$ & 210 & 4.593 & 3.823 & .293 & 15.646 \\
\hline URB & 1411 & 48.447 & 23.287 & 8.246 & 100 & URB & 238 & 54.297 & 13.102 & 26.501 & 77.661 \\
\hline LIT & 1411 & 104.891 & 15.769 & 32.322 & 154.744 & LIT & 238 & 99.526 & 5.878 & 87.135 & 124.893 \\
\hline ILEB & 1411 & 4.189 & .147 & 3.75 & 4.412 & ILEB & 238 & 4.257 & .044 & 4.127 & 4.359 \\
\hline ICBR & 1411 & 3.219 & .382 & 2.067 & 3.98 & ICBR & 238 & 2.676 & .367 & 2.041 & 3.473 \\
\hline UNE & 1411 & 7.082 & 6.166 & .14 & 36.147 & UNE & 238 & 11.844 & 7.167 & 3.694 & 37.25 \\
\hline POP65 & 1411 & 4.916 & 2.488 & .715 & 15.042 & POP65 & 238 & 10.047 & 4.089 & 2.945 & 17.423 \\
\hline
\end{tabular}

Note: Derived from research data.

The result stated that all of the variables are significant for specific income classified countries or one this classification, and the worldwide, but only these two variables LE, and POP65 are significant for the whole world and also for the income classified countries.

Table 2: Result of Macroeconomic Determinants of Health Expenditure Worldwide

\begin{tabular}{|c|c|c|c|c|c|c|}
\hline \multirow[t]{2}{*}{ Variables } & \multicolumn{2}{|c|}{ Pooled OLS } & \multicolumn{2}{|c|}{ REM } & \multicolumn{2}{|c|}{ FEM } \\
\hline & $\begin{array}{l}\text { Coefficient } \\
\text { (CE) }\end{array}$ & $\begin{array}{l}\text { t-values } \\
\text { (T. V) }\end{array}$ & $\begin{array}{l}\text { Coefficient } \\
\text { (CE) }\end{array}$ & $\begin{array}{l}\text { t-values } \\
\text { (T. V) }\end{array}$ & $\begin{array}{l}\text { Coefficient } \\
\text { (CE) }\end{array}$ & $\begin{array}{c}\text { t-values } \\
\text { (T. V) }\end{array}$ \\
\hline FDI & $0.0069^{* *}$ & $(2.83)$ & 0.00170 & $(1.36)$ & 0.00154 & $(1.24)$ \\
\hline PR & $0.0198 * *$ & $(2.92)$ & 0.00635 & $(0.99)$ & 0.00356 & $(0.53)$ \\
\hline TO & $-0.0029 * *$ & $(-2.75)$ & $-0.00276^{* *}$ & $(-2.90)$ & $-0.00317 * *$ & $(-3.20)$ \\
\hline LnGDP & 0.0241 & $(0.92)$ & 0.0753 & (1.04) & 0.235 & $(1.56)$ \\
\hline $\mathrm{CO} 2$ & 0.0118 & (1.37) & $-0.0453 * *$ & $(-3.18)$ & $-0.0360 *$ & $(-2.11)$ \\
\hline URB & $0.00658 *$ & $(2.18)$ & -0.00601 & $(-0.77)$ & -0.0242 & $(-1.84)$ \\
\hline LnLIT & $0.0264 * * *$ & $(8.28)$ & $0.00870 * *$ & $(2.98)$ & $0.00745^{*}$ & $(2.48)$ \\
\hline LnLEB & $1.884 * * *$ & $(3.46)$ & $4.817 * * *$ & (6.97) & $5.195 * * *$ & $(6.01)$ \\
\hline LnCBR & $2.978 * * *$ & (12.59) & $1.405 * * *$ & $(5.47)$ & $0.860 * *$ & $(2.95)$ \\
\hline UNE & $0.0450 * * *$ & $(5.83)$ & $0.0353 * * *$ & (4.04) & $0.0370 * * *$ & (3.90) \\
\hline POP65 & $0.425 * * *$ & (25.09) & $0.341 * * *$ & (13.15) & $0.382 * * *$ & (11.66) \\
\hline Constant & $-18.00 * * *$ & $(-6.13)$ & $-23.44 * * *$ & $(-7.71)$ & $-26.65 * * *$ & $(-7.60)$ \\
\hline $\mathrm{T}$ & \multicolumn{2}{|c|}{17} & \multicolumn{2}{|c|}{17} & \multicolumn{2}{|c|}{17} \\
\hline $\mathrm{N}$ & \multicolumn{2}{|c|}{132} & \multicolumn{2}{|c|}{132} & \multicolumn{2}{|c|}{132} \\
\hline $\mathrm{N}$ & \multicolumn{2}{|c|}{1,980} & \multicolumn{2}{|c|}{1,980} & \multicolumn{2}{|c|}{1,980} \\
\hline F-stat [Wald $\left.\chi^{2}\right]$ & \multicolumn{2}{|c|}{114.38} & \multicolumn{2}{|c|}{382.52} & \multicolumn{2}{|c|}{29.66} \\
\hline $\mathrm{P}$-value & \multicolumn{2}{|c|}{0.0000} & \multicolumn{2}{|c|}{0.0000} & \multicolumn{2}{|c|}{0.0000} \\
\hline \multicolumn{7}{|l|}{ Diagnostic Tests } \\
\hline & \multicolumn{4}{|c|}{ Breusch and Pagan LM test } & \multicolumn{2}{|c|}{ Hausman test } \\
\hline Prob. > chibar2 & \multicolumn{4}{|c|}{0.0000} & \multicolumn{2}{|c|}{0.0002} \\
\hline
\end{tabular}


Table 3: Result of Macroeconomic Determinants of Health Expenditures in Developed Countries

\begin{tabular}{|c|c|c|c|c|c|c|}
\hline \multirow[t]{2}{*}{ Variables } & \multicolumn{2}{|c|}{ Pooled OLS } & \multicolumn{2}{|c|}{ REM } & \multicolumn{2}{|c|}{ FEM } \\
\hline & $\mathrm{CE}$ & T. V & $\mathrm{CE}$ & T. V & $\mathrm{CE}$ & T. V \\
\hline FDI & 0.00297 & $(1.45)$ & 0.00135 & (1.54) & 0.000941 & (1.08) \\
\hline PR & 0.0844 & (1.27) & 0.0249 & $(0.67)$ & 0.0228 & $(0.60)$ \\
\hline TO & -0.000919 & $(-0.62)$ & $0.00971 * * *$ & $(-5.25)$ & $-0.0134 * * *$ & $(-6.71)$ \\
\hline LnGDP & $0.568 * * *$ & $(9.90)$ & $0.555 * * *$ & $(3.51)$ & $1.708 * * *$ & $(4.16)$ \\
\hline $\mathrm{CO} 2$ & -0.0141 & $(-0.73)$ & $-0.146^{* * *}$ & $(-4.92)$ & $-0.168 * * *$ & $(-5.26)$ \\
\hline URB & $0.0172 *$ & $(2.58)$ & $0.0782 * * *$ & $(4.54)$ & $0.121 * * *$ & $(4.69)$ \\
\hline LnLIT & 0.0263 & $(1.75)$ & $0.0271 * *$ & (3.04) & $0.0246 * *$ & (2.79) \\
\hline LnLEB & $19.16 * * *$ & $(8.96)$ & $17.76 * * *$ & (5.93) & $11.09 * *$ & $(3.09)$ \\
\hline LnCBR & 1.020 & (1.61) & $1.482 * *$ & (3.11) & $1.407 * *$ & $(2.78)$ \\
\hline UNE & -0.0134 & $(-0.79)$ & $0.0261 *$ & $(2.50)$ & $0.0392 * *$ & $(3.29)$ \\
\hline POP65 & 0.0139 & $(0.35)$ & $0.151 * * *$ & $(3.49)$ & $0.155^{* * *}$ & $(3.36)$ \\
\hline Constant & $-96.57 * * *$ & $(-10.98)$ & $-96.15 * * *$ & $(-8.53)$ & $-99.68 * * *$ & $(-7.94)$ \\
\hline $\mathrm{T}$ & & & 1 & & 1 & \\
\hline $\mathrm{N}$ & & & 3. & & 3 & \\
\hline $\mathrm{N}$ & & & 52 & & 5 & \\
\hline F-stat [Wald $\left.\chi^{2}\right]$ & & & 564 & & 53 & \\
\hline $\mathrm{P}$-value & 0.0 & & 0.00 & & 0.0 & \\
\hline \multicolumn{7}{|l|}{ Diagnostic Tests } \\
\hline & \multicolumn{4}{|c|}{ Breusch and Pagan LM test } & \multicolumn{2}{|c|}{ Hausman test } \\
\hline Prob. > chibar2 & \multicolumn{4}{|c|}{0.0000} & \multicolumn{2}{|c|}{0.0000} \\
\hline
\end{tabular}

An adverse and statistically significant relationship exists among foreign direct investment and health expenditure only for the sample of developing countries. As foreign direct investment rates increase, a country tends to decrease health expenditure. And our result is supported by (Unver \& Erdogan, 2015).

Table 3: Result of Macroeconomic Determinants of Health Expenditure in Transitional Countries

\begin{tabular}{|c|c|c|c|c|c|c|}
\hline \multirow[t]{2}{*}{ Variables } & \multicolumn{2}{|c|}{ Pooled OLS } & \multicolumn{2}{|c|}{ FEM } & \multicolumn{2}{|c|}{ REM } \\
\hline & $\mathrm{CE}$ & T. V & $\mathrm{CE}$ & T. V & $\mathrm{CE}$ & T. V \\
\hline FDI & 0.0108 & $(0.80)$ & $0.0363^{*}$ & $(2.46)$ & 0.0261 & (1.89) \\
\hline PR & $0.0488 * * *$ & (4.02) & $0.0349 *$ & $(2.48)$ & $0.0457 * * *$ & (3.53) \\
\hline TO & 0.0000303 & $(0.01)$ & 0.000990 & $(0.20)$ & 0.00154 & $(0.33)$ \\
\hline LnGDP & -0.0281 & $(-0.19)$ & 0.359 & $(0.67)$ & 0.330 & (1.32) \\
\hline $\mathrm{CO} 2$ & -0.0210 & $(-0.43)$ & -0.147 & $(-1.43)$ & -0.0945 & $(-1.19)$ \\
\hline URB & $-0.0866 * * *$ & $(-5.36)$ & -0.0796 & $(-1.26)$ & $-0.0778 *$ & $(-2.15)$ \\
\hline LnLIT & $-0.0419 *$ & $(-2.52)$ & -0.0185 & $(-1.13)$ & -0.0113 & $(-0.73)$ \\
\hline LnLEB & 5.244 & $(1.73)$ & 11.27 & $(1.69)$ & $9.778 *$ & $(2.27)$ \\
\hline LnCBR & $-2.025 * * *$ & $(-3.95)$ & 0.623 & $(0.56)$ & -0.444 & $(-0.53)$ \\
\hline UNE & -0.00192 & $(-0.11)$ & $0.0977 * *$ & $(2.80)$ & $0.0664 *$ & $(2.39)$ \\
\hline POP65 & $0.253 * * *$ & $(4.66)$ & 0.0134 & $(0.08)$ & $0.217^{*}$ & $(2.10)$ \\
\hline Constant & -3.905 & $(-0.28)$ & $-47.25 *$ & $(-2.22)$ & $-40.13 *$ & $(-2.34)$ \\
\hline $\mathrm{T}$ & \multicolumn{2}{|c|}{17} & \multicolumn{2}{|c|}{17} & \multicolumn{2}{|c|}{17} \\
\hline $\mathrm{N}$ & \multicolumn{2}{|c|}{14} & \multicolumn{2}{|c|}{14} & \multicolumn{2}{|c|}{14} \\
\hline $\mathrm{N}$ & \multicolumn{2}{|c|}{210} & \multicolumn{2}{|c|}{210} & \multicolumn{2}{|c|}{210} \\
\hline F-stat [Wald $\left.\chi^{2}\right]$ & \multicolumn{2}{|c|}{28.29} & \multicolumn{2}{|c|}{4.61} & \multicolumn{2}{|c|}{66.90} \\
\hline $\mathrm{P}$-value & \multicolumn{2}{|c|}{0.0000} & \multicolumn{2}{|c|}{0.0000} & \multicolumn{2}{|c|}{0.0000} \\
\hline \multicolumn{7}{|l|}{ Diagnostic Tests } \\
\hline & \multicolumn{4}{|c|}{ Breusch and Pagan LM test } & \multicolumn{2}{|c|}{ Hausman test } \\
\hline Prob. > chibar2 & \multicolumn{4}{|c|}{0.0000} & \multicolumn{2}{|c|}{0.7572} \\
\hline
\end{tabular}

Source: Author's own computations. $* * *, * *, *$ indicates at $1 \%, 5 \% \& 10 \%$ level of significance, respectively. 
Nagel and Herzer (2015) the negative relationship was due to the rise of greater income inequality in the host countries. Furthermore, our result is contradictory to the theory of Herzer and Nunnenkamp (2012) FDI has a direct effect inside firms, economy-wide while aberrant consequences for prosperity might follow from FDI-initiated development to the degree that higher normal earnings bring about more interest in wellbeing administrations. Mixed results were achieved between personal remittances and health expenditure. While the positive and statistically significant result is achieved in transitional countries, the developing countries recorded negative and statistically significant results. This finding for developing countries supported by the study of Ebeke (2012) and the result for transitional countries supported by (Gil, 2009; Dorantes \& Pozo, 2009; Ponce et al., 2011).

Table 4: Result of Macroeconomic Determinants of Health Expenditure in Developing Countries

\begin{tabular}{|c|c|c|c|c|c|c|}
\hline \multirow[t]{2}{*}{ Variables } & \multicolumn{2}{|c|}{ Pooled OLS } & \multicolumn{2}{|c|}{ REM } & \multicolumn{2}{|c|}{ FEM } \\
\hline & $\mathrm{CE}$ & T. V & $\mathrm{CE}$ & T. V & $\mathrm{CE}$ & T. V \\
\hline FDI & 0.0143 & $(1.15)$ & -0.0140 & $(-1.73)$ & $-0.0202 *$ & $(-2.47)$ \\
\hline PR & $-0.0175 *$ & $(-2.19)$ & $-0.0391 * * *$ & $(-4.02)$ & $-0.0482 * * *$ & $(-4.76)$ \\
\hline TO & -0.00267 & $(-1.83)$ & -0.00132 & $(-1.15)$ & -0.00125 & $(-1.07)$ \\
\hline LnGDP & $-0.0903 * *$ & $(-3.05)$ & -0.0775 & $(-0.91)$ & -0.0594 & $(-0.27)$ \\
\hline $\mathrm{CO} 2$ & $-0.0228 *$ & $(-2.20)$ & -0.0157 & $(-0.95)$ & 0.0190 & $(0.86)$ \\
\hline URB & $0.0119 * * *$ & $(3.56)$ & -0.0134 & $(-1.55)$ & $-0.0377^{*}$ & $(-2.37)$ \\
\hline LnLIT & $0.0324 * * *$ & (10.24) & $0.0148 * * *$ & $(4.53)$ & $0.0132 * * *$ & $(3.96)$ \\
\hline LnLEB & -0.202 & $(-0.32)$ & $3.496 * * *$ & (4.43) & $4.772 * * *$ & $(4.85)$ \\
\hline LnCBR & $2.095 * * *$ & $(6.56)$ & 0.423 & $(1.01)$ & -0.714 & $(-1.35)$ \\
\hline UNE & $0.0509 * * *$ & $(5.45)$ & 0.0158 & (1.13) & 0.0110 & $(0.69)$ \\
\hline POP65 & $0.339 * * *$ & $(9.20)$ & $0.377 * * *$ & $(6.56)$ & $0.421 * * *$ & $(5.44)$ \\
\hline Constant & -3.993 & $(-1.09)$ & $-11.17^{*}$ & $(-2.57)$ & $-12.17 *$ & $(-2.05)$ \\
\hline $\mathrm{T}$ & & & 1 & & 1 & \\
\hline $\mathrm{N}$ & & & 8 & & 8 & \\
\hline $\mathrm{N}$ & & & 1,2 & & 1,2 & \\
\hline F-stat [Wald $\chi^{2}$ ] & & & 129 & & 14 & \\
\hline $\mathrm{P}$-value & 0.0 & & 0.0 & & 0.0 & \\
\hline \multicolumn{7}{|l|}{ Diagnostic Tests } \\
\hline & \multicolumn{4}{|c|}{ Breusch and Pagan LM test } & \multicolumn{2}{|c|}{ Hausman test } \\
\hline Prob. > chibar 2 & \multicolumn{4}{|c|}{0.0000} & \multicolumn{2}{|c|}{0.0000} \\
\hline
\end{tabular}

A statistically important and adverse association exists among trade openness and H.E at the global level and developed countries. This study's result is contradictory to the study of Herzer (2017). According to Herzer (2017) trade openness led to rising income level and income leads to rising the expenditure in both private and public, on goods that improve health. A positive and statistically significant result is noted among GDP and well-being spending. Furthermore, the findings show that GDP increases, well-being spending also increases. This result is according to theory of Samadi \& $\operatorname{Rad}(2003)$ "nations with the great monetary foundation have more information about the advantages of medical services and thusly use medical care more than different nations". There is a statistically significant and negative affiliation among CO2 emission and health expenditure for the sample of worldwide, and the developed countries. This negative link is supported by the following works (Lu et al., 2017; Boachie et al., 2014).

Twin result was achieved between the urbanization and the health expenditures. While the positive and statistically significant result is achieved in developed countries, the developing and transitional economies recorded a negative and statistically significant result. And our 
positive result is supported by Rezaei et al. (2016) while the negative findings were supported by Cumper (1984), Siddiqui et al. (1995). Further, higher education level in the society leads to more awareness about health which leads to raise the consumption of wellbeing care facilities. There is a positive and statistically significant association between literacy and H.E worldwide, developed countries, and developing countries. And this result is supported by (Toor \& Butt, 2005).

Life expectancy increases the share of the population of the elderly and is positively associated with health expenditure. So, there is a positive and momentous relationship amongt LE and wellbeing expenditure for the full sample of worldwide, developed, transitional, and developing countries. This positive association is supported by the following study (Akca $e t$ al.,2017 and Moayedfard et al., 2020). Likewise, the effect of crude birth is positive and statistically significant for the sample of worldwide and developed countries because the crude birth rate increases the maintenance cost of given health. And this finding is supported by (Leu, 1985 and Toor \& Butt, 2005). In the same way, the effect of unemployment on wellbeing spending is positive and statistically significant worldwide, developed countries, and transitional countries. This result is supported by (Braendle \& Colombier, 2016). Moreover, there is a statistically positive and significant association among the age of the population above 65 and H.E in all the sample groups i.e., worldwide, developed, developing, and transitional countries. This finding is under (Murthy \& Okunade, 2016).

\section{Conclusion and Suggestions}

The present study explores the key determinants of H.E for the world, and income-based categorized countries i.e., developed countries, developing countries, and transitional countries correspondingly. The data has been retrieved from the world development indicator (2019) and due to data availability panel of 132 countries was constructed from the period 2000-2016. The finding of the study shows that foreign direct investment (FDI) and personal remittances (PR) have a noteworthy influence on H.E in developing countries with the negative sign, but personal remittances is a significant impact on H.E in transitional countries with a positive sign. Moreover, GDP is significant with a positive impact on H.E in developed countries while trade openness and $\mathrm{CO} 2 \mathrm{E}$ is a significant impact on H.E in the world and developed countries with a negative sign. In the same context, urbanization has a positive and significant impact on H.E in developed countries, while the significant and negative impact in transitional and developing countries. Likewise, literacy has a significant positive outcome on well-being expenditure worldwide, developed, and developing countries.

Similarly, LE at birth and POP65 have a noteworthy and positive impact on health expenditure in the world, and income-based categorized countries. Furthermore, there is a positive and significant affiliation among unemployment and health expenditure worldwide, developed countries, transitional countries while crude birth rate only in the world, and developed countries. Such studies are of great importance, the health expenditure in all parts of the economy is one of an emerging issue. According to Yetima et al. (2020), a dramatic increase in health expenditure everywhere in the world have obligatory for the countries to underline the issues related to H.E. So, the current study helps the policymakers to understand the several variables and their relationship with health expenditure. And based on these relationships helps policymakers to make long-term decisions. Based on the finding of the study, we recommend that the following policy combat the problem of health expenditure. 
The governments should put into operation such kind of policy to make simpler for travelers to send settlements back to their home The impact of migrants' income on health is consistent and sustained. The positive effect shows that the governments should open such sorts of channels through which settlements stream increments and this stream builds the extra cash of the family level, which might be put resources into improving lodging conditions or increment the accessibility of food. The governments should adopt such kind of policy which promotes the formal channel of inflow of remittances rather than informal. And give surety to the migrants' household that they can receive remittances at any time with no barriers.

Furthermore, the governments should introduce a sustainable production process to mitigate the impact of $\mathrm{CO} 2$ emission by concerning international institutes like the United Nations Environmental Program, the World Trade Organization, and the World Health Organization. Such an organization plays a vital role in advising and guiding countries. However, the need for further empirical analysis and investigating relevant variables and hopefully improved further. It can be extended by changing the size of the data, structure of the data, and also applying different techniques for estimation. The study can also be extended to find out the determinant of H.E for all regions and the study is also extended to make an index of macroeconomic variables.

\section{References}

Abbas, F., \& Hiemenz, U. (2011). Determinants of public health expenditures in Pakistan. ZEF-Discussion Papers on Development Policy, (158). SSRN: https://ssrn.com/abstract=1967070

Akca, N., Sonmez, S., \& Yilmaz, A. (2017). Determinants of health expenditure in OECD countries: A decision tree model. Pakistan Journal of Medical Sciences, 33(6), 1490. https://doi.org/10.12669/pjms.336.13300

Alsan, M., Bloom, D. E., \& Canning, D. (2006). The effect of population health on foreign direct investment inflows to low-and middle-income countries. World Development, 34(4), 613-630. https://doi.org/10.1016/j.worlddev.2005.09.006

Amuedo-Dorantes, C., \& Pozo, S. (2011). New evidence on the role of remittances on healthcare expenditures by Mexican households. Review of Economics of the Household, 9(1), 69-98. https://doi.org/10.1007/s11150-009-9080-7

Apergis, N., Gupta, R., Lau, C. K. M., \& Mukherjee, Z. (2018). US state-level carbon dioxide emissions: Does it affect health care expenditure? Renewable and Sustainable Energy Reviews, 91, 521-530. https://doi.org/10.1016/j.rser.2018.03.035

Aremu, O. (2019). Past, present, and future of global health financing: a review of development assistance, government, out-of-pocket, and other private spending on health for 195 countries, 2 1995-2050. The Lancet. https://dx.doi.org/10.1016/S01406736(19)30841-4

Atuahene, S. A., Yusheng, K., \& Bentum-Micah, G. (2020). Health Expenditure, CO2 Emissions, and Economic Growth: China vs. India.

Baltagi, B. H., \& Moscone, F. (2010). Health care expenditure and income in the OECD reconsidered: Evidence from panel data. Economic Modelling, 27(4), 804-811. https://doi.org/10.1016/j.econmod.2009.12.001 
Bech, M., Christiansen, T., Khoman, E., Lauridsen, J., \& Weale, M. (2011). Ageing and health care expenditure in EU-15. The European Journal of Health Economics, 12(5), 469478. https://doi.org/10.1007/s10198-010-0260-4

Boachie, M. K., Mensah, I. O., Sobiesuo, P., Immurana, M., Iddrisu, A. A., \& Kyei-Brobbey, I. (2014). Determinants of public health expenditure in Ghana: a cointegration analysis. Journal of Behavioural Economics, Finance, Entrepreneurship, Accounting and Transport, 2(2), 35-40. https://doi.org/10.12691/jbe-2-2-1

Braendle, T., \& Colombier, C. (2016). What drives public health care expenditure growth? Evidence from Swiss cantons, 1970-2012. Health Policy, 120(9), 1051-1060. https://doi.org/10.1016/j.healthpol.2016.07.009

Clift, C. (2013). The Role of the World Health Organization in the International System. Chatham House. https://www.researchgate.net/profile/Charles-Clift2/publication/291097805_The_Role_of the_World_Health_Organization_in the_In ternational_System/links/569e074c08ae16fdf07b11ae/The-Role-of-the-WorldHealth-Organization-in-the-International-System.pdf.

Cumper, G. E. (1984). Determinants of health levels in developing countries. Research Studies Press. https://www.cabdirect.org/cabdirect/abstract/19852023924

Di Matteo, L. (2005). The macro determinants of health expenditure in the United States and Canada: assessing the impact of income, age distribution and time. Health Policy, 71(1), 23-42. https://doi.org/10.1016/j.healthpol.2004.05.007

El-Farouk, A. E., Banjar, F. M., Karar, H. M., \& Elamin, F. O. (2016). Determinants of public healthcare expenditure in Saudi Arabia. Eur J Pharm Med Res, 3(12), 85-93.

Freeman, D. G. (2003). Is health care a necessity or a luxury? Pooled estimates of income elasticity from US state-level data. Applied Economics, 35(5), 495-502. https://doi.org/10.1080/00036840210138374

Gbesemete, K. P., \& Gerdtham, U. G. (1992). Determinants of health care expenditure in Africa: a cross-sectional study. World Development, 20(2), 303-308. https://doi.org/10.1016/0305-750X(92)90108-8

Gerdtham, U. G., Søgaard, J., Andersson, F., \& Jönsson, B. (1992). An econometric analysis of health care expenditure: a cross-section study of the OECD countries. Journal of Health Economics, 11(1), 63-84. https://doi.org/10.1016/0167-6296(92)90025-V

Grossman, M. (1972). On the concept of health capital and the demand for health. Journal of Political Economy, 80(2), 223-255. https://doi.org/10.1086/259880

Han, K., Cho, M., \& Chun, K. (2013). Determinants of health care expenditures and the contribution of associated factors: 16 cities and provinces in Korea, 20032010. Journal of Preventive Medicine and Public Health, 46(6), 300. https://doi.orh/10.3961/jpmph.2013.46.6.300

Herzer, D. (2017). The Long-run relationship between trade and population health: Evidence from five decades. The World Economy, 40(2), 462-487. https://doi.org/10.1111/twec.12419

Herzer, D., \& Nunnenkamp, P. (2012). FDI and health in developed economies: A panel cointegration analysis (No. 1756). Kiel Working Paper.

Hitiris, T., \& Posnett, J. (1992). The determinants and effects of health expenditure in developed countries. Journal of Health Economics, 11(2), 173-181. https://doi.org/10.1016/0167-6296(92)90033-W

Hubert Ebeke, C. (2012). Do remittances lead to a public moral hazard in developing countries? An empirical investigation. Journal of Development Studies, 48(8), 1009-1025. https://doi.org/10.1080/00220388.2011.615918 
Khoshnevis Yazdi, S., \& Khanalizadeh, B. (2017). Air pollution, economic growth and health care expenditure. Economic Research-Ekonomska Istraživanja,30(1), 1181-1190. https://doi.org/10.1080/1331677X.2017.1314823

Lindgren, B. (2004). Individual Decisions for Health. Taylor \& Francis e-Library.

Lu, Z. N., Chen, H., Hao, Y., Wang, J., Song, X., \& Mok, T. M. (2017). The dynamic relationship between environmental pollution, economic development and public health: Evidence from China. Journal of Cleaner Production, 166, 134-147. https://doi.org/10.1016/j.jclepro.2017.08.010

Manda, D. K., Mugo, M. G., \& Murunga, J. (2020). Health Expenditures and Health Outcomes in Kenya. https://doi.org/10.19044/esj.2020.v16n22p95

McGuire, A., Parkin, D., Hughes, D., \& Gerard, K. (1993). Econometric analyses of national health expenditures: can positive economics help to answer normative questions? Health Economics, 2(2), 113-126. https://doi.org/10.1002/hec.4730020205

Mishra, P., \& Newhouse, D. (2009). Does health aid matter? Journal of Health Economics, 28(4), 855-872. https://doi.org/10.1016/j.jhealeco.2009.05.004

Moayedfard, A., Ghorbani, S., \& Sefiddashti, S. E. (2020). Health Expenditure and Its Human Capital Determinants in Iran. Iranian Journal of Public Health.

Mostepaniuk, A., \& Mohammadreza, P. (2019). Determinants of health status in high income countries. Молодий вчений, 2(1), 240-243.

Murthy, V. N., \& Okunade, A. A. (2016). Determinants of US health expenditure: Evidence from autoregressive distributed lag (ARDL) approach to cointegration. Economic Modelling, 59, 67-73. https://doi.org/10.1016/j.econmod.2016.07.001

Nagel, K., Herzer, D., \& Nunnenkamp, P. (2015). How does FDI affect health? International Economic Journal, 29(4), 655-679. https://doi.org/10.1080/10168737.2015.1103772

Narayan, P. K., \& Narayan, S. (2008). Does environmental quality influence health expenditures? Empirical evidence from a panel of selected OECD countries. Ecological Economics, 65(2), 367-374. https://doi.org/10.1016/j.ecolecon.2007.07.005

Newhouse, J. P. (1977). Medical-care expenditure: a cross-national survey. The Journal of Human Resources, 12(1), 115-125. https://doi.org/10.2307/145602

Nixon, J. \& Ulmann, P. (2006). The relationship between health and care expenditure and health outcomes. The European Journal of Health Economics, 7: 7-18. https://doi.org/10.1007/s10198-005-0336-8

Novignon, J., \& Atakorah, Y. B. (2016). How does the health sector benefit from trade openness? Evidence from panel data across sub-Saharan Africa countries. African Development Review, 30(2), 135-148. https://doi.org/10.1111/1467-8268.12319

Owen, A. L., \& Wu, S. (2007). Is trade good for your health? Review of International Economics, 15(4), 660-682. https://doi.org/10.1111/j.1467-9396.2007.00677.x

Ponce, J., Olivié, I., \& Onofa, M. (2011). The role of international remittances in health outcomes in Ecuador: prevention and response to shocks. International Migration Review, 45(3), 727-745. https://doi.org/10.1111/j.1747-7379.2011.00864.x

Rezaei, S., Fallah, R., Karyani, A. K., Daroudi, R., Zandiyan, H., \& Hajizadeh, M. (2016). Determinants of healthcare expenditures in Iran: evidence from a time series analysis. Medical Journal of the Islamic Republic of Iran, 30, 313.

Samadi, A., \& Rad, E. H. (2013). Determinants of Healthcare Expenditure in Economic Cooperation Organization (ECO) Countries: Evidence from Panel Cointegration 
Tests. International Journal of Health Policy and Management, 1(1), 63. https://doi.org/10.15171/ijhpm.2013.10

Siddiqui, R., Afridi, U., Haq, R., \& Tirmazi, S. H. (1995). Determinants of Expenditure on Health in Pakistan [with Comments]. The Pakistan Development Review, 34(4), 959970. https://www.jstor.org/stable/41259915

Toor, I. A., \& Butt, M. S. (2005). Determinants of health care expenditure in Pakistan. Pakistan Economic and Social Review, 133-150. https://www.jstor.org/stable/25825266

Unver, M., \& Erdogan, M. (2015). Social effects of foreign direct investments: International empirical evidence for education, health and social security. International Research Journal of Finance and Economics, 132, 7-19.

Valero Gil, J. N. (2009). Remittances and the household's expenditures on health. Journal of Business Strategies, 26(1), 119-140. http://eprints.uanl.mx/id/eprint/7523

WHO. (2015). From MDGs to SDGs: General Introduction. World Health Organization.

WHO. (2016). Monitoring Health for the SDGs, World Health Organization.

WHO. (2018). Monitoring Health for the SDGs, World Health Organization.

WHO. (2018). New Perspectives on Global Health Spending for Universal Health Coverage, World Health Organization.

Yetim, B., İlgün, G., Çilhoroz, Y., Demirci, Ş., \& Konca, M. (2020). The socioeconomic determinants of health expenditure in OECD: An examination on panel data. International Journal of Healthcare Management, $1-5$. https://doi.org/10.1080/20479700.2020.1756112 